Dapat diakses pada: http://jkb.ub.ac.id/index.php/jkb/article/view/1826

Jurnal Kedokteran Brawijaya Vol. 29, No. 04, Agustus 2017, pp. 348-352

Online Published First: 13 Juni 2017

Artikel Penelitian

Article History: Received 5 September 2016, Accepted 29 Desember 2016

\title{
Analisis Konsentrasi Low Density Lipoprotein Teroksidasi Serum pada Tahapan Aterosklerosis
}

\section{Analysis of Serum Oxidized Low Density Lipoprotein Concentration at Atherosclerosis Stages}

\author{
Ismawati ${ }^{1}$, Fadil Oenzil', Yanwirasti ${ }^{3}$, Eti Yerizel ${ }^{2}$ \\ ${ }^{1}$ KJF Biokimia Fakultas Kedokteran Universitas Riau \\ ${ }^{2}$ Departemen Biokimia Fakultas Kedokteran Universitas Andalas Riau \\ ${ }^{3}$ Departemen Anatomi Fakultas Kedokteran Universitas Andalas Riau
}

\begin{abstract}
ABSTRAK
Aterosklerosis merupakan proses yang terjadi secara bertahap meliputi tahap inisiasi, progresi dan komplikasi. Beberapa penelitian memperlihatkan kaitan antara stres oksidatif dengan aterosklerosis, tetapi belum ada penelitian yang menganalisis perbedaan stres oksidatif pada berbagai tahap aterosklerosis. Konsentrasi oxidized low density lipoprotein (oxLDL) menggambarkan stres oksidatif yang terjadi sehingga dikenal sebagai marker stres oksidatif. Penelitian ini bertujuan untuk menganalisis konsentrasi oxLDL serum pada berbagai tahap aterosklerosis pada hewan coba. Pada penelitian ini dilakukan pengukuran kadar oxLDL serum pada 24 ekor tikus yang terdiri dari kelompok normal, inisiasi, progresi dan komplikasi. Induksi aterosklerosis dilakukan dengan pemberian vitamin D3 (700.000 IU $/ \mathrm{kg})$ dan pakan tinggi lipid (kolesterol 2\%, lemak kambing 5\%, asam kolat 0,2\%) masing-masing selama 2 hari, 4 hari dan 2 minggu. Konsentrasi oxLDL serum diukur dengan teknik Enzyme linked immunosorbent assays (ELISA). Data disajikan sebagai rata-rata \pm SD. Uji statistik yang digunakan adalah uji Anova. Konsentrasi oxLDL serum lebih tinggi pada inisiasi dibandingkan normal $(2,17 \pm 0,26 \mathrm{ng} / \mathrm{mL}$ versus $1,93 \pm 0,25 \mathrm{ng} / \mathrm{mL}, \mathrm{p}>0,05)$ dan lebih tinggi lagi pada progresi dan komplikasi $(2,75 \pm 0,25 \mathrm{ng} / \mathrm{mL}$ dan $3,3 \pm 0,61 \mathrm{ng} / \mathrm{mL}, p<0,05)$ masing-masing terhadap normal dan inisiasi). Penelitian ini menyimpulkan bahwa terdapat perbedaan konsentrasi oxLDL pada berbagai tahap aterosklerosis dan konsentrasi paling tinggi pada tahap komplikasi. Hal ini membuka kemungkinan untuk mengembangkan oxLDL sebagai marker tahapan aterosklerosis.
\end{abstract}

Kata Kunci: Aterosklerosis, oxLDL, stres oksidatif

\begin{abstract}
Atherosclerosis is a slow disease and can be divided into stages of initiation, progression and complication. Some research has found a correlation between stress oxidative and atherosclerosis, but there has been no research that compares oxidative stress at each of these stages. Oxidized Low Density Lipoprotein (oxLDL) concentration reflect oxidative stress so is widely used as a marker of oxidative stress. This study aimed to investigated the concentration of serum oxLDL at different stages of atherosclerosis using rat model. The sample consists of 18 wistar rats with atherosclerosis (stage of initiation, progression and complication) and 6 normal wistar rats. Induction of atherosclerosis done by vitamin D3 $(700,000 \mathrm{lU} / \mathrm{kg}$ ) and high feed lipids (2\% cholesterol, 5\% goat fat and 0.2\% cholic acid) each for 2 days, 4 days and 2 weeks. Serum oxidized LDL (oxLDL) concentration was measured by Enzyme linked immunosorbent assays (ELISA). Data are presented as mean $\pm S D$. Analysis of variance test was used to compare mean value of ox $L D L$ concentration. Serum ox $L D L$ concentration was higher in initiation compared with normal $(2,17 \pm 0,26 \mathrm{ng} / \mathrm{mL}$ versus $1,93 \pm 0,25 \mathrm{ng} / \mathrm{mL}, \mathrm{p}>0,05$ and further higher in progression and complication $(2,75 \pm 0,25 \mathrm{ng} / \mathrm{mL}$ and $3,3 \pm 0,61 \mathrm{ng} / \mathrm{mL}, p<0,05$ versus normal and initiation for each). This study concludes that there are different concentrations of serum oxLDL at the stages of atherosclerosis. Serum oxLDL concentration is highest in complication. This result may be used in research into new marker in atherosclerosis.
\end{abstract}

Keywords: Atherosclerosis, oxidative stress, oxLDL

Korespondensi: Ismawati. KJF Biokimia Fakultas Kedokteran Universitas Riau, Jl. Diponegoro no 1 Pekanbaru, 28133, Tel. 085217065890 Email: ismawati75@yahoo.com

DOI: http://dx.doi.org/10.21776/ub.jkb.2017.029.04.11 


\section{PENDAHULUAN}

Aterosklerosis merupakan masalah yang semakin meningkat pada saat ini, karena mempunyai risiko yang tinggi untuk terjadinya penyakit kardiovaskuler (PKV). Kematian akibat PKV meningkat setiap tahunnya, dan merupakan $30 \%$ penyebab kematian di dunia pada tahun 2005 (1). Diperkirakan pada tahun 2020 akan menjadi penyebab utama kematian yang ada di dunia (2).

Proses aterosklerosis terjadi dalam waktu yang lama dan bertahap (3). Berdasarkan perjalanan klinis, aterosklerosis dapat dibagi atas tahap inisiasi, progresi dan komplikasi yang berupa angina stabil dan angina tidak stabil (4). Proses aterosklerosis diawali pada masa anak-anak dan manifestasi klinis terjadi pada usia menengah dan lanjut. Proses aterosklerosis terjadi secara perlahan-lahan, sehingga pasien tidak menyadarinya, sampai kemudian timbul manifestasi seperti angina tidak stabil, infark miokard akut atau kematian mendadak. Oleh sebab itu penting untuk lebih memahami patogenesis aterosklerosis sehingga aterosklerosis bisa dideteksi lebih dini dan dapat ditatalaksana dengan baik (5).

Beberapa penelitian memperlihatkan bahwa stres oksidatif berperan dalam terjadinya aterosklerosis (6). Stres oksidatif terjadi akibat ketidakseimbangan radikal bebas dengan antioksidan. Radikal bebas adalah atom atau molekul yang elektron terluarnya tidak mempunyai pasangan, sangat reaktif dan mampu bereaksi dengan molekul disekitarnya (7). Lipid yang terdapat pada lipoprotein low density lipoprotein (LDL) rentan terhadap radikal bebas. Lipoprotein yang telah teroksidasi ini akan difagositosis oleh makrofag membentuk sel busa. Fagositosis oleh sel netrofil, monosit dan limfosit juga akan menghasilkan radikal bebas sehingga akan meningkatkan stres oksidatif (8). Jika radikal bebas menyerang lipid akan menginduksi terjadinya peroksidasi lipid. Peroksidasi lipid berlangsung melalui beberapa tahap yaitu inisiasi, propagasi dan terminasi (9). Akhir dari reaksi ini adalah terputusnya rantai asam lemak menjadi berbagai senyawa yang bersifat toksik terhadap sel, seperti malondialdehid (MDA), 9-hidroksi-nonenal (HNE), serta berbagai hidrokarbon seperti etana dan pentana (10).

Ada berbagai marker yang dapat digunakan untuk mendeteksi aterosklerosis, tetapi sangat sedikit marker untuk mendeteksi tahap aterosklerosis mengingat aterosklerosis merupakan proses yang sangat kompleks. Beberapa proses tidak terjadi pada satu tahap saja bahkan berlangsung pada seluruh tahap, sehingga marker yang berkaitan dengan proses ini akan terdeteksi sepanjang aterosklerosis. Beberapa marker yang dapat digunakan mendeteksi tahap inisiasi: Monocyte Chemotactic Protein 1 (MCP-1), Macrophage Colony Stimulating Factor (MCSF) dan CRP. Marker lain seperti Vascular Endothelial Growth Factor (VEGF) dan Troponin I telah diteliti sebagai marker tahap progresi dan tahap komplikasi aterosklerosis. Low Density Lipoprotein teroksidasi merupakan marker aterosklerosis yang terdeteksi sepanjang tahap aterosklerosis dan berkaitan dengan kerusakan sel endotel, inflamasi dan stres oksidatif (4).

Pada penelitian ini digunakan hewan coba berupa tikus putih. Berbagai hewan coba telah digunakan untuk penelitian aterosklerosis seperti primata, babi, kelinci, marmut, tikus dan mencit. Hewan coba yang kecil seperti tikus cukup menjanjikan untuk digunakan dalam penelitian aterosklerosis. Tikus memiliki beberapa kelebihan karena praktis, mudah didapat dan pola makan tikus yang omnivora lebih mirip manusia dibandingkan kelinci. Meskipun demikian, tikus sebenarnya resisten terhadap aterosklerosis, tetapi dengan modifikasi seperti pemberian tiourasil, vitamin D3 atau adrenalin bersama diet tinggi kolesterol maka tikus dapat diinduksi aterosklerosis (11). Penggunaan vitamin D3 dosis tinggi berperan pada terjadinya kalsifikasi vaskuler, proliferasi sel otot polos dan menstimulus migrasi sel otot polos pembuluh darah (12).

Berdasarkan latar belakang diatas, peneliti tertarik untuk mengetahui lebih jauh tentang konsentrasi LDL teroksidasi serum pada berbagai tahap aterosklerosis. Penelitian ini penting dilakukan karena dengan mengetahui konsentrasi oxLDL pada tiap tahap aterosklerosis akan diketahui tingkat stres oksidatif pada tiap tahap tersebut.

\section{METODE}

Penelitian ini telah mendapatkan persetujuan etik dari Tim Komite Etika Penelitian Fakultas Kedokteran Universitas Andalas dengan surat kelaikan etik nomor 269/KEP/FK/2013. Pada penelitian ini digunakan tikus putih (Rattus norvegicus) galur wistar sebagai model aterosklerosis. Sebanyak 28 ekor tikus berumur 2-3 bulan dibagi secara acak dalam 4 kelompok yaitu kelompok kontrol $(K)$, inisiasi $\left(P_{1}\right)$, progresi $\left(P_{2}\right)$ dan komplikasi $\left(P_{3}\right)$. Kelompok K merupakan kelompok yang mendapatkan diet standar. Kelompok $\mathrm{P}_{1}, \mathrm{P}_{2}$ dan $\mathrm{P}_{3}$ merupakan kelompok tikus yang diinduksi aterosklerosis. Sampel diberikan perlakuan berupa vitamin D3 (11-12), diet aterogenik berupa kolesterol $2 \%$, lemak kambing $5 \%$, asam kolat $0,2 \%$ dan diet standar sampai dengan $100 \%$ (13). Diet aterogenik diberikan dalam bentuk pelet $20 \mathrm{~g} /$ hari/ekor dan minuman diberikan ad libitum, diperiksa dan ditambah setiap hari. Vitamin D3 (Biotech Pharmacal) $700.000 \mathrm{IU} / \mathrm{kg}$ diberikan dosis tunggal pada hari pertama induksi dengan cara intubasi lambung (11-12). Penelitian pendahuluan mendapatkan bahwa lama pemberian diet aterogenik untuk masing-masing kelompok adalah $\mathrm{P}_{1}$ (2 hari), $\mathrm{P}_{2}$ (4 hari) dan $\mathrm{P}_{3}$ (2 minggu).

Pada waktu yang telah ditentukan, dilakukan pengambilan aorta abdominal dan darah dari jantung. Selanjutnya dilakukan pemeriksaan histopatologis aorta abdominal dengan skoring sebagai berikut: 0: normal; 1: pelebaran serat elastik dengan sedikit sel busa; 2 : fragmentasi lamela elastika dengan sejumlah sel busa dan fibrosis/kalsifikasi, proliferasi sel otot polos, infiltrasi lipid medial; 3: plak ulseratif/trombus (14). Penentuan derajat aterosklerosis dilakukan dengan penilaian pada 9 lapangan pandang (pembesaran $400 \mathrm{x}$ ) dan skor yang diambil adalah nilai yang tertinggi dari 9 lapangan pandang tersebut. Hasil pemeriksaan kemudian diinterprestasikan dengan kriteria 0: normal, 1: inisiasi, 2: proliferasi dan 3: komplikasi (14). Sampel yang memenuhi syarat selanjutnya akan dilakukan pemeriksaan oxLDL serum dengan teknik ELISA. Uji Anova merupakan uji statistik yang digunakan untuk membandingkan konsentrasi oxLDL serum antar kelompok dan dilanjutkan dengan uji posthoc. Nilai $p<0,05$ dikatakan bermakna secara statistik.

\section{HASIL}

Hasil pengamatan histopatologis menunjukkan, bahwa skor aterosklerosis dari yang tertinggi sampai terendah berturut-turut adalah kelompok $\mathrm{P}_{3}, \mathrm{P}_{2}, \mathrm{P}_{1}$, dan $\mathrm{K}$ (Tabel 1). 
Pemberian vitamin D3 dan diet aterogenik pada penelitian ini telah berhasil mendapatkan tikus model tahapan aterosklerosis. Hal ini terlihat dari persentase terbentuknya lesi aterosklerosis pada masing-masing kelompok yaitu $85,71 \%$ pada kelompok $\mathrm{P}_{1}, 85,71 \%$ pada kelompok $\mathrm{P}_{2}$ dan $100 \%$ pada kelompok $\mathrm{P}_{3}$.

Tabel 1. Skoring pemeriksaan histopatologis (HE) aorta abdominal tikus

\begin{tabular}{ccccc}
\hline \multirow{2}{*}{ Ulangan } & \multicolumn{4}{c}{ Skor pemeriksaan histopatologis } \\
& $\mathbf{K}$ & $\mathbf{P}_{\mathbf{1}}$ & $\mathbf{P}_{\mathbf{2}}$ & $\mathbf{P}_{\mathbf{3}}$ \\
\hline 1 & 0 & 0 & 2 & 3 \\
2 & 0 & 1 & 2 & 3 \\
3 & 0 & 1 & 2 & 3 \\
4 & 0 & 1 & 2 & 3 \\
5 & 0 & 1 & 2 & 3 \\
6 & 0 & 1 & 2 & 3 \\
7 & 0 & 1 & 0 & 3 \\
\hline
\end{tabular}

Hasil pemeriksaan histopatologis pada aorta abdominal kelompok yang diberi diet aterogenik dan vitamin D3 sebagian besar terlihat adanya penebalan dinding dan membran elastika interna terlihat rusak (Gambar 1). Lesi aterosklerosis tahap inisiasi ditandai adanya sel busa (Gambar 1A). Tahap progresi ditandai adanya kalsifikasi, sel otot polos terlihat berproliferasi, serat otot polos terganggu serta proliferasi jaringan ikat (fibrosis) (Gambar 1B). Lesi aterosklerosis pada tahap komplikasi ditandai adanya plakulseratif (Gambar 1C).

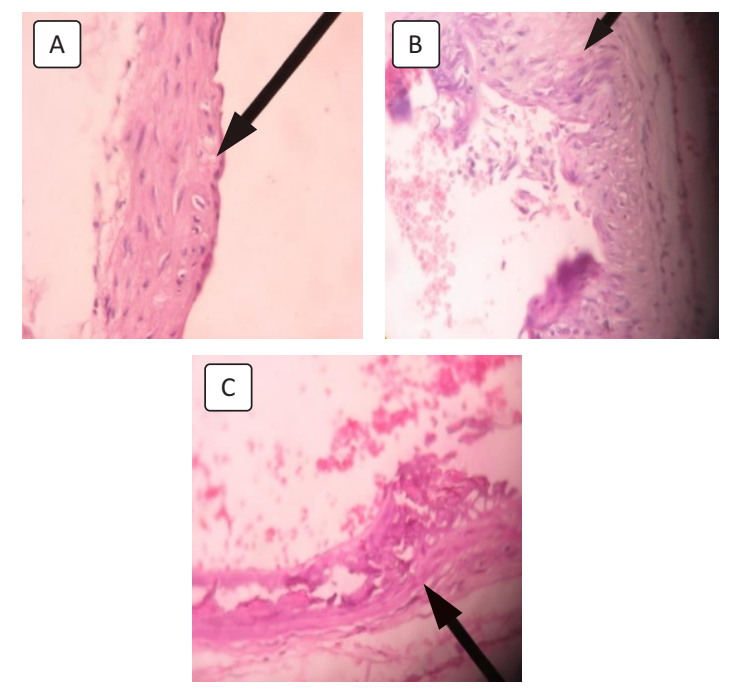

Gambar 1. Histopatologis aorta abdominal (HE, 400x) Keterangan:

A. Tahap inisiasi, panah menunjukkan sel busa

B. Tahap progresi, panah menunjukkan kalsifikasi dan fibrosis.

C. Tahap komplikasi, panah menunjukkkan ulseratif.

Pengukuran konsentrasi oxLDL serum dilakukan pada 24 sampel karena terdapat 2 buah sampel yang darahnya mengalami lisis yaitu dari kelompok $\mathrm{K}$ dan $\mathrm{P}_{3}$. Tabel 2 menunjukkan bahwa konsentrasi oxLDL tertinggi terdapat pada tahap komplikasi diikuti oleh tahap progresi, inisiasi dan normal. Data yang disajikan memperlihatkan terdapat peningkatan konsentrasi oxLDL serum pada semua tahap aterosklerosis dibandingkan normal. Hasil pengukuran konsentrasi oxLDL serum menunjukkan adanya peningkatan konsentrasi oxLDL serum yang berbanding lurus dengan progresivitas lesi aterosklerosis. Semakin lanjut tahap aterosklerosis, maka semakin tinggi pula peningkatan konsentrasi oxLDL serum.

Tabel 2. Perbedaan rerata konsentrasi LDL teroksidasi serum berdasarkan kelompok

\begin{tabular}{llc}
\hline Kelompok & $\mathbf{n}$ & $\begin{array}{c}\text { Konsentrasi LDL teroksidasi serum } \\
(\mathbf{n g} / \mathbf{m L}) \text { Rata } \pm \text { SD }\end{array}$ \\
\hline Normal & 6 & $1,93 \pm 0,25$ \\
Inisiasi & 6 & $2,17 \pm 0,26^{\mathrm{c}, \mathrm{d}}$ \\
Progresi & 6 & $2,75 \pm 0,25^{\mathrm{a}, \mathrm{b}, \mathrm{d}}$ \\
Komplikasi & 6 & $3,30 \pm 0,61^{\mathrm{a}, \mathrm{b}, \mathrm{c}}$ \\
\hline
\end{tabular}

Keterangan: ${ }^{a} p<0,05$ vs normal, ${ }^{b} p<0,05$ vs inisiasi, ${ }^{c} p<0,05$ vs progresi, , d $p<0,05$ vs komplikasi

Uji statistik memperlihatkan terdapat perbedaan yang bermakna konsentrasi oxLDL berdasarkan kelompok (Tabel 2). Tidak didapatkan perbedaan konsentrasi oxLDL yang bermakna secara statistik antara kelompok inisiasi dengan kelompok normal. Perbedaan konsentrasi oxLDL yang bermakna dengan kelompok normal baru terdapat pada kelompok progresi dan perbedaan itu semakin jelas pada kelompok komplikasi.

\section{DISKUSI}

Pada penelitian ini dilakukan induksi aterosklerosis selama 2 hari, 4 hari dan 2 minggu. Hasil induksi aterosklerosis selama 2 hari menghasilkan lesi berupa sel busa (tahap inisiasi). Induksi aterosklerosis selama 4 hari menghasilkan lesi berupa sel busa, proliferasi otot polos, fibrosis/kalsifikasi (tahap progresi). Lesi aterosklerosis berupa defek permukaan/ulserasi didapatkan setelah melakukan induksi selama 2 minggu. Lama induksi aterosklerosis ini lebih pendek jika dibandingkan penelitian lain. Penelitian Pang et al, melakukan induksi aterosklerosis pada tikus putih Sprague Dawley selama 12 minggu dan mendapatkan lesi aterosklerosis berupa sel busa, kalsifikasi dan plak ulseratif (12). Penelitian Li et al, melakukan induksi aterosklerosis selama 15 minggu dan lesi aterosklerosis berupa sel busa, fibrosis dan kalsifikasi (11). Penelitian yang dilakukan Jiang et al, mendapatkan lesi aterosklerosis setelah melakukan induksi aterosklerosis selama 6 minggu. Perbedaan waktu yang diperlukan ini kemungkinan akibat adanya perbedaan cara pemberian vitamin D3, komposisi diet aterogenik yang diberikan dan strain tikus putih yang digunakan (15-17).

Berbagai penelitian telah dilakukan untuk mengetahui hubungan antara konsentrasi oxLDL dengan aterosklerosis. Belum ada penelitian mengenai hubungan konsentrasi oxLDL dengan tahap aterosklerosis pada jaringan. Beberapa penelitian menganalisis hubungan antara konsentrasi oxLDL sirkulasi dengan aterosklerosis subklinis (18-19) dan derajat penyakit jantung koroner (20). Kato et al, meneliti hubungan antara konsentrasi oxLDL plasma dengan luasnya lesi aterosklerosis pada mencit Apo E-KO (Apolipoptein E Knockout) yang diberi diet standar (21). 
Pada penelitian ini didapatkan peningkatan oxLDL pada tahap inisiasi dan progresi, meskipun peningkatan yang bermakna hanya pada tahap progresi. Hasil penelitian yang diperoleh ini sejalan dengan penelitian Verhoye et al. dan Holvoet et al, yang mendapatkan peningkatan oxLDL berbanding lurus dengan Intima Media Thickness (IMT) pada pasien dengan aterosklerosis subklinis (18-19). Jika dihubungkan dengan tahap aterosklerosis maka aterosklerosis subklinis tersebut merupakan tahap progresi aterosklerosis. Pada tahap ini telah terjadi perubahan pada pembuluh darah tetapi belum menunjukkan gejala klinis.

Pada penelitian ini juga didapatkan peningkatan konsentrasi oxLDL serum pada tahap komplikasi. Bahkan konsentrasi oxLDL paling tinggi terdapat pada tahap komplikasi dan berbeda bermakna dengan tahap progresi. Penelitian Gomez et al, juga mendapatkan terdapat hubungan antara konsentrasi oxLDL sirkulasi dengan kejadian penyakit jantung koroner. Jika dihubungkan dengan tahap aterosklerosis maka aterosklerosis yang telah menunjukkan gejala klinis merupakan tahap komplikasi (20).

Kato et al, mendapatkan peningkatan oxLDL plasma tidak berbanding lurus dengan luasnya lesi aterosklerosis. Konsentrasi oxLDL paling tinggi justru terjadi saat luas lesi aterosklerosis masih minimal. Perbedaan ini kemungkinan karena perbedaan perlakuan yang diberikan, hewan coba yang digunakan dan aspek penilaian aterosklerosisnya. Pada penelitian Kato et al, hiperkolesterolemia terjadi pada mencit karena kelainan genetik (mencit ApoE-KO), bukan karena pemberian diet aterogenik. Aspek penilaian aterosklerosis juga berbeda, Kato et al, tidak menilai berdasarkan tahap aterosklerosis tetapi berdasarkan luas lesi aterosklerosis yang belum tentu sama dengan tahap aterosklerosisnya (21).

Proses oksidasi LDL kemungkinan terjadi pada dinding vaskuler lebih besar dibandingkan plasma karena plasma kaya akan antioksidan. Klirens oxLDL sirkulasi dilakukan oleh sistem retikuloendotelial terjadi dengan cepat yaitu dalam hitungan menit. Meskipun demikian, berbagai teknik pengukuran dapat mendeteksi adanya oxLDL sirkulasi. Konsentrasi oxLDL sirkulasi merupakan gambaran dari oxLDL total, meskipun asalnya belum diketahui pasti. Sumber oxLDL sirkulasi kemungkinan dari daerah inflamasi di perifer dan dinding vaskuler (22).

Pada penelitian ini didapatkan peningkatan oxLDL berbanding lurus dengan tahap aterosklerosis. Jika dihubungkan dengan peranan oxLDL sebagai marker stres oksidatif maka terlihat adanya peningkatan stres oksidatif mulai dari tahap inisiasi sampai tahap komplikasi. Hal ini sejalan dengan penelitian Uno and Nicholls yang mendapatkan peningkatan stres oksidatif terjadi secara

\section{DAFTAR PUSTAKA}

1. Alsheikh-Ali AA, Kitsios GD, Balk EM, Lau J, and Ip S. The Vulnerable Atherosclerotic Plaque: Scope of the Literature. Annals of Internal Medicine. 2010; 153(6): 387-395.

2. Srinivasa-Rao PVLN and Kiranmayi VS. Biochemical Mechanism Underlying Atherogenesis. Journal of Clinical and Scientific Research. 2012; 1:24-34.

3. Mizuno Y, Jacob RF, and Mason RP. Inflammation and bermakna pada tahap progresi dan komplikasi (23). Hasil ini juga sejalan dengan didapatkannya penurunan ekspresi proteasom pada tahap komplikasi dibandingkan tahap progresi (14). Penurunan aktivitas proteasom ini kemungkinan akibat stres oksidatif yang berkepanjangan akan menginaktifkan proteasom dan selanjutnya menghambat aktivasi NF-kB dengan menghambat degradasi I-KB (24).

Peranan LDL pada tahap inisiasi aterosklerosis dimulai masuknya partikel LDL ke dalam dinding arteri diikuti oleh retensi apolipoprotein B100 oleh komponen proteoglikan matriks ekstraseluler. Partikel LDL yang terperangkap ini selanjutnya akan mengalami oksidasi ringan. Partikel ini memiliki kemampuan proinflamasi yang menonjol dan merupakan mediator awal inflamasi kronik melalui aktivasi NF-KB atau jalur lainnya (25). Partikel ini menstimulasi sel vaskuler untuk menghasilkan MCP-1 (monocyte chemotatic protein-1), granulosit dan MCSF (macrophage colony stimulating factor). Molekul-molekul ini mempromosikan rekruitment monosit dan diferensiasinya menjadi makrofag yang selanjutnya nenstimulus oksidasi LDL melalui myeloperoksidase dan SOR sehingga LDL teroksidasi sempurna. Partikel LDL yang teroksidasi sempurna ditandai oleh peningkatan muatan negatif apolipoprotein $\mathrm{B} 100$ yang dikenal oleh reseptor scavenger makrofag, selanjutnya diinternalisasi untuk membentuk sel busa. Selanjutnya makrofag berperan melalui produksi interleukin 1 dan TNF (26).

Peranan oxLDL pada tahap progresi melalui peningkatan ekspresi PDGF (platelet derived growth factor) dan FGF (fibroblast growth factor) oleh sel endotel dan makrofag, yang selanjutnya berperan pada proliferasi SMCs. Mekanisme oxLDL meningkatkan ekspresi PDGF dan FGF belum diketahui. Selain itu oxLDL juga menstimulasi produksi kolagen oleh SMCs (26).

Peranan oxLDL pada tahap komplikasi aterosklerosis terjadi melalui peningkatan degradasi matriks ekstraseluler akibat peningkatan ekspresi MMP-1 dan MMP-9. Peningkatan ekspresi MMP-1 oleh oxLDL terjadi secara sinergis dengan faktor pertumbuhan dan sitokin yaitu TNF- $\alpha$ dan GM-CSF melalui jalur COX-2 dan PGE 2 . Demikian juga dengan peningkatan ekspresi MMP-9 terjadi secara sinergis dengan faktor pertumbuhan (PDGF dan FGF) dan sitokin (TNF $\alpha$ dan IL-1 $\alpha$ ) dan juga NF-KB sebagai faktor transkripsi (27).

Penelitian ini menyimpulkan bahwa terdapat perbedaan konsentrasi oxLDL pada tahap aterosklerosis. Konsentrasi oxLDL serum paling tinggi terdapat pada tahap komplikasi, diikuti oleh progresi dan inisiasi. Hal ini membuka kemungkinan untuk mengembangkan oxLDL sebagai marker tahapan aterosklerosis.

the Development of Atherosclerosis. Journal of Atherosclerosis and Thrombosis. 2011; 18(5): 351358.

4. Parthasarathy S. Atherogenesis. 1st edition. Rijeka: Intech; 2012; p. 187-202.

5. Insull W. The Pathology of Atherosclerosis: Plaque Development and Plaque Responses to Medical Treatment. The American Journal of Medicine. 2009; 122(1): S3-S14. 
6. Vogiatzi G, Tousoulis D, and Stefanadis C. The Role of Oxidative Stress in Atherosclerosis. Hellenic Journal of Cardiology. 2009; 50(5): 402-409.

7. Halliwell B and Gutteridge JMC. Free Radicals in Biology and Medicine. 4th edition. New York: Oxford University Press; 2007; pp. 625-638.

8. Murray RK, Bender DA, Botham KM, Kennelly PJ, Rodwell VW, and Weil PA. Harper's Illustrated Biochemistry. 26th edition. USA: McGraw-Hill Companies; 2012; pp. 80-236.

9. Gueraud F, Atalay $\mathrm{M}$, et al. Chemistry and Biochemistry of Lipid Peroxidation Products. Free Radical Research. 2010;44(10): 1098-1124.

10. Ismawati, Asni E, dan Hamidy MY. Pengaruh Air Perasan Umbi Bawang Merah (Allium ascalonicumL.) terhadap Malondialdehid (MDA) Plasma Mencit yang diinduksi Hiperkolesterolemia. Jurnal Natur Indonesia. 2012; 14(2): 150-154.

11. Li J, Chen CX and Shen YH. Effects of Total Glucosides from Paeony (Paeonialactiflora Pall) Roots on Experimental Atherosclerosis in Rats. Journal of Ethnopharmacology. 2011; 135(2): 469-475.

12. Pang J, Xu Q, Xu X, et al. Hexarelin Suppresses High Lipid Diet and Vitamin D3-Induced Atherosclerosis in the Rat. Peptides. 2010; 31(4): 630-638.

13. Lukitasari N, Ratnawati R, dan Lyrawati D. Polifenol Buah Tin (Ficus carica Linn) Menghambat Peningkatan Kadar MCP-1 pada Tikus dengan Diet Tinggi Lemak. Jurnal Kedokteran Brawijaya. 2014; 8(1): 1-5.

14. Ismawati, Oenzil F, Yanwirasti, and Yerizel E. Changes in Expression of Proteasome in Rats at Different Stages of Atherosclerosis. Anatomy \& Cell Biology. 2016; 49(2): 99-106.

15. Jiang F, Qian J, Chen S, Zhang W, and Liu C. Ligustrazine Improves Atherosclerosis in Rat via Attenuation of Oxidative Stress. Pharmaceutical Biology. 2011; 49(8): 856-863.

16. Getz GS and Reardon CA. Animal Models of Atherosclerosis. Arteriosclerosis, Thrombosis and Vascular Biology. 2012; 32(5): 1104-1115.

17. Jawien J. The Role of An Experimental Model of Atherosclerosis: apoE-knockout Mice in Developing
New Drugs against Atherogenesis. Current Pharmaceutical Biotechnology. 2012; 13(13): 24352439.

18. Verhoye E and Langlois MR. Circulating Oxidized LowDensity Lipoprotein: A Biomarker of Atherosclerosis and Cardiovascular Risk? Clinical Chemistry and Laboratory Medicine. 2009; 47(2): 128-137.

19. Holvoet P, Jenny NS, Schreiner PJ, Tracy RP, and Jacobs DR. The Relationship Between Oxidized LDL and Other Cardiovascular Risk Factors and Subclinical CVD in Different Ethnic Groups: The MultiEthnic Study of Atherosclerosis (MESA). Atherosclerosis. 2007; 194(1): 245-252.

20. Gomez M, Vila J, Elosua R, et al. Relationship of Lipid Oxidation with Subclinical Atherosclerosis and 10Year Coronary Events in General Population. Atherosclerosis. 2014; 232(1): 134-140.

21. Kato R, Mori C, Kitazato K, et al. Transient Increase in Plasma Oxidized LDL During the Progression of Atherosclerosis in Apolipoprotein E Knockout Mice. Arteriosclerosis, Thrombosis, and Vascular Biology. 2009; 29(1): 33-39.

22. Itabe H. Oxidative Modification of LDL: Its Pathological Role in Atherosclerosis. Clinical Reviews in Allergy \& Immunology. 2009; 37(1): 4-11.

23. Uno $\mathrm{K}$ and Nicholls SJ. Biomarkers of Inflammation and Oxidative Stress in Atherosclerosis. Biomarkers in Medicine.2010;4(3):361-373.

24. Wu M, Bian Q, Liu Y, et al. Sustained Oxidative Stress Inhibits NF-KB Activation Partially vialnactivating the Proteasome. Free Radical Biology \& Medicine. 2009; 46(1): 62-69.

25. Bui QT, Prempeh M, and Wilensky RL. Atherosclerotic Plaque Development. The International Journal of Biochemistry \& Cell Biology. 2009; 41(11): 2109-2113.

26. Maiolino G, Rossitto G, Caielli P, Bisogni V, Rossi GP, and Calo LA. The Role of Oxidized Low-Density Lipoproteins in Atherosclerosis: The Myths and the Facts. Mediators of Inflammation. 2013; 2013: 1-13.

27. Back M, Ketelhuth DFJ, and Agewall S. Matrix Metalloproteinases in Atherothrombosis. Progress in Cardiovascular Diseases. 2010; 52(5): 410-428. 